\title{
The EU and its Perilous Journey through the Migration Crisis: Informalisation of the EU
}

\section{Return Policy and Rule of Law Concerns}

\section{Caterina Molinari *}

\section{KU Leuven}

(Contacts: caterina.molinari@kuleuven.be - KU Leuven Institute for European Law, Tiensestraat 41, 3000 Leuven, Belgium - +32470560774)

An earlier version of this paper was presented at the $25^{\text {th }}$ KU Leuven Law Alumni Day and included in the syllabus of the event.

Subject: European Union. Other subjects: external relations, migration.

Keywords: EU external relations, migration, return, rule of law.

Abstract: The cooperation between the European Union ('EU' or 'Union') and third countries on return and readmission of irregular migrants is increasingly informal, namely enshrined in political or administrative deals rather than formal international treaties. This article explores the effect of the systematisation in the use of informal deals on the rule of law compliance of the Union's return policy. It argues that the systematic recourse to informal deals relates to a strategic avoidance of judicial and democratic accountability of the Union's action. More particularly, EU institutions make use of the distinction between international treaties and non-binding informal deals to severe an area of governance with clear fundamental rights implications, i.e. the EU return policy, from judicial and democratic oversight. This compromises the rule of law compliance of the EU return policy. In fact, as constitutional principle of the EU legal order, the rule of law inextricably connects and encompasses pre-eminence of the law, democratic guarantees, and fundamental rights protection.

\footnotetext{
* Caterina Molinari is a PhD Fellow of the Research Foundation - Flanders (FWO), working at the KU Leuven Institute for European Law. Her research focuses on the external relations of the EU in the field of migration, more specifically on the constitutionality of the EU return policy.
} 


\section{Introduction: Preparing the Journey}

\section{Preamble}

The European Union ('EU' or 'Union') pursues the objectives of its migration policy through both internal action and the development of forms of cooperation with third countries, requested to readmit irregular migrants on their territory. The area of the EU migration policy dealing with the expulsion of irregular migrants towards their countries of origin or transit countries is the so-called 'return policy'. Over time, expelling irregular migrants has become a priority of the Union's approach towards migration, ${ }^{1}$ characterised by a tendency to outsource migration management to third countries. ${ }^{2}$ The EU return policy has also gained visibility in the political discourse of EU institutions and Member States, as reflected by several political documents issued by the Commission and the European Council in the last years. ${ }^{3}$

\footnotetext{
${ }^{1}$ R. Bossong and H. Carrapico, "The Multidimensional Nature and Dynamic Transformation of European Borders and Internal Security", in R. Bossong and H. Carrapico (eds), EU Borders and Shifting Internal
} Security: Technology, Externalization and Accountability (Heidelberg: Springer, 2016), pp.12-14; B. Frelick, I. M. Kysel, and J. Podkul, “The Impact of Externalization of Migration Controls on the Rights of Asylum Seekers and Other Migrants" (2016) 4 Journal of Migration and Human Security 190, 193-196; and Cassarino, "Informalizing the EU Readmission Policy", in A. Ripoll Servent and F. Trauner (eds), The Routledge Handbook of Justice and Home Affairs Research (Routledge: London, 2018), p.91.

${ }^{2}$ M. Casas Cortez, S. Cobarrubias, and J. Pickles, "Riding Routes and itinerant Borders: Autonomy of Migration and Border Externalisation" (2015) 47 Antipode 894; G. Papagianni, "Forging an External EU Migration Policy" (2013) 15 European Journal of Migration and Law 283, 284 and 291; Y. Ryabov, "The Externalisation of Migration Control in the European Union: First Steps towards the External Dimension of the Space of Freedom, Security and Justice" (2012) 4 Baltic Region 44, 47-49; A. Benantar, "Complexe de sécurité ouestméditerranéen : externalisation et sécurisation de la migration” (2013) IX L’Année du Maghreb 57.

${ }^{3}$ Commission, "Establishing a New Partnership Framework with Third Countries under the European Agenda on Migration" $\operatorname{COM(2016)~} 385$ final; European Council Conclusions, 17 and 18 March 2016; Commission, “A European Agenda on Migration" COM(2015) 240 final; Commission, "Making Returns More Effective When Implementing the Directive 2008/115/EC of the European Parliament and of the Council" C(2017) 1600 final; 
The current prominence of the EU return policy warrants a short digression on its history.

The development of an autonomous EU return policy started in 1999, with the entry into force of the Amsterdam Treaty. ${ }^{4}$ The latter implicitly conferred upon the EU the competence to conclude return agreements with third countries, now explicitly provided for in art. 79(3) of the Treaty on the Functioning of the European Union ('TFEU'). The newly attributed power allowed the Union to launch negotiations for the conclusion of readmission treaties with third countries, based on which the first four mandates for negotiation were issued in the year $2000 . .^{5}$ The progress of the negotiations proved to be lengthy and difficult, mainly due to the need to identify credible incentives for the nonEU countries required to cooperate. ${ }^{6}$ One of the four negotiating mandates never led to the signature of the desired treaty (with Morocco), while the others resulted in readmission agreements that could only enter into force in 2005 (Sri Lanka), 2007 (Russia), and 2010 (Pakistan) respectively. ${ }^{7}$ Similar difficulties kept resurfacing, as new negotiations were launched over the following years.

Commission, "EU Action Plan on Return" $\operatorname{COM(2015)~} 453$ final; European Council Conclusions, 25 and 26 June 2015; Commission, "A More Effective Return Policy in the European Union - A Renewed Action Plan" COM (2017) 200 final; S. Carrera, Implementation of EU Readmission Agreements: Identity Determination Dilemmas and the Blurring of Rights (London: Springer International, 2016), p.8

${ }^{4}$ Treaty of Amsterdam amending the Treaty on European Union, the Treaties establishing the European Communities and certain related acts, [1997] OJ C 340/1.

${ }^{5}$ J.-P. Cassarino, "Readmission Policy in the European Union” (2010) European Parliament Study, pp.14-15.

${ }^{6}$ N. Coleman, European Readmission Policy: Third Country Interests and Refugee Rights (Leiden: Martinus Nijhoff, 2009), p.209.

7 See list of EU readmission agreements available at https://ec.europa.eu/home-affairs/what-wedo/policies/irregular-migration-return-policy/return-readmission_en. 
The situation prompted a reflection on new approaches that would render the EU return policy more effective. This resulted in the flexibilisation and informalisation of the tools used to pursue the return objective, namely in the use, together with readmission treaties, of other types of deals capable of achieving similar goals. ${ }^{8}$ More particularly, the new EU Agency for the Management of Operational Cooperation at the External Borders of the Member States of the European Union (Frontex) was granted the power to conclude administrative arrangements with third countries. ${ }^{9}$ In addition, after the Commission's Communication on the Global Approach to Migration and Mobility of $2011,{ }^{10}$ bilateral negotiations on the issue of return were conducted increasingly within the informal framework of flexible and broader political dialogues called mobility partnerships and common agendas for migration and mobility. ${ }^{11}$

\footnotetext{
${ }^{8}$ Cassarino, "Readmission Policy in the European Union" (2010), pp.26-38. See also P. Slominski and F. Trauner, "How Do Member States Return Unwanted Migrants? The Strategic (Non-) Use of 'Europe' during the Migration Crisis” (2018) 56 Journal of Common Market Studies 101.

${ }^{9}$ Article 14 Council Regulation (EC) No 2007/2004 of 26 October 2004 establishing a European Agency for the Management of Operational Cooperation at the External Borders of the Member States of the European Union [2004] OJ L 349/1.

${ }^{10}$ Commission, "The Global Approach to Migration and Mobility" COM(2011) 743 final.

${ }^{11}$ P. García Andrade and I. Martín, "EU Cooperation with Third Countries in the Field of Migration" (2015) European Parliament Study, pp.28-34; see also S. Brocza and K. Paulhart, "EU Mobility Partnerships: A Smart Instrument for the Externalization of Migration Control” (2015) 3 European Journal of Futures Research 1.
} 
The drive for flexibility was not tamed by the entry into force of the new treaty framework governing the Union's external relations in $2009 .{ }^{12}$ On the contrary, and especially after the outbreak of the migration crisis in 2015 , the use of informal tools in the field of return became systematic, ${ }^{13}$ allowing the EU to bypass, in the name of urgency, the new substantive and procedural rules applicable to international treaties after the Lisbon reform.

This article examines the above developments and attempts to answer the following research question: does the systematisation in the use of informal tools affect the rule of law compliance of the Union's return policy?

Before delving into the core of our analysis, we will attempt to define the concept of informalisation, and to frame the rule of law principle and its implications for the Union's external action. We will then answer the research question by (i) showing that the EU return policy has indeed been informalised in an increasingly systematic manner; and (ii) demonstrating that this systematic informalisation hindered the applicability of the rule of law guarantees designed to govern the Union's external action. We will conclude that the systematisation in the use of informal tools to pursue the objectives of the EU return policy relates to a strategic avoidance of democratic and judicial accountability in the field and is, therefore, incompatible with the rule of law principle.

\footnotetext{
${ }^{12}$ Treaty of Lisbon amending the Treaty on European Union and the Treaty establishing the European Community, signed at Lisbon, 13 December 2007, [2007] OJ C 306/1.

${ }^{13}$ M. Panizzon, "The Global Migration Compact and the Limits of 'Package Deals' for Migration Law and Policy", in T. Gammeltoft-Hansen, E. Guild et al. "What Is a Compact? Migrants' Rights and State Responsibilities Regarding the Design of the UN Global Compact for Safe, Orderly and Regular Migration" RWI Working Paper 1/2017, p.21.
} 


\section{The Concept of Informalisation}

In the context of the most recent literature on EU migration law, ${ }^{14}$ the term "informalisation" refers to the increasing reliance on non-traditional instruments of international cooperation. The latter differ from formal international treaties, negotiated and concluded according to pre-established procedures, because of their allegedly political or administrative nature and because of the generalised lack of clarity concerning their legal effects, namely their suitability to create rights and obligations. When dealing with the issue of return and readmission of irregular migrants, the Union's institutions and their counterparties often show a preference for statements and arrangements different from fully fledged international treaties. The concept of informalisation aptly illustrates this preference, recently exemplified by the arrangements called "Standard Operating Procedures", that the Commission has concluded with Bangladesh ${ }^{15}$ and negotiated with Mali. ${ }^{16}$

The reasons underlying the tendency towards informalisation are multiple and range from the need to respond to emergency situations in a swift manner, ${ }^{17}$ to the much stated (and little justified and

${ }^{14}$ See, for example, Cassarino, "Informalizing the EU Readmission Policy” (2018), Slominski and Trauner, “How do Member States Return Unwanted Migrants?” (2018), L. Gabrielli, La "Externalización Europea Del Control Migratorio. ¿La Acción Española Como Modelo?” in J. Arango, R. Mahía, D. Moya, and E. SánchezMontijano (eds), Anuario CIDOB de la Inmigración 2017 - La inmigración en el ojo del huracán, (Barcelona: CIDOB, 2017), p.126.

15 "EU-Bangladesh Standard Operating Procedures for the Identification and Return of Persons without an Authorisation to Stay", text available as Annex 1 to Commission, "Decision on the signature of the EUBangladesh Standard Operating Procedures for the Identification and Return of Persons without an Authorisation to Stay" C(2017) 6137 final.

${ }^{16}$ Annex to Council, "Draft Standard Operating Procedures between the EU and the Republic of Mali for the identification and return of persons without an authorisation to stay", Item Note 15050/16, http://www.statewatch.org/news/2016/dec/eu-council-standard-operating-procedures-mali-return-15050-16.pdf

[Accessed 11 October 2018].

${ }^{17}$ Commission "Commission contribution to the EU Leaders' thematic debate on a way forward on the external and the internal dimension of migration policy", COM (2017) 820 final, p.1. 
explained) need for flexibility. ${ }^{18}$ They also encompass the willingness to remain outside the strict, regimented, and controlled frame of hard law, avoiding the relevant scrutiny. ${ }^{19}$ This last reason is particularly problematic, as it links with a strategic avoidance of accountability in sensitive areas of the Union's action, that has the potential to exempt them almost entirely from the rule of law mechanisms proper to the Union's constitutional order.

\section{The Rule of Law: Studying the Map}

\section{The Rule of Law Principle ...}

The "rule of law" is an essential constitutional principle of the EU legal order. It is listed among the fundamental values of the Union in art. 2 of the Treaty on the European Union ('TEU'), and recognised as a value common to the Member States in the respective preambles of the TEU and of the EU Charter of Fundamental Rights. Respect for this principle is a condition for accession of new Member States to the Union under art. 49 TEU, and a continual obligation of EU institutions as well as of Member States, as proven by the possible political sanctions that art. 7 TEU envisages in case of non-compliance. The rule of law is not only a principle to be respected internally, but also one of the values to be promoted by the Union when acting as a normative power on the international plan, according to art. 3(5) TEU. Article 21(1) TEU requires the Union to be "guided by" the rule of law principle when acting externally. The link between art. 3(5) and art. 21(1) TEU is clear: only if its own external action complies with the rule of law principle, can the EU act as a normative power and “export” such principle.

\footnotetext{
${ }^{18}$ Letter of the director general of DG HOME to the Chair of the EP LIBE Committee, "EU readmission developments - State of play", October 2017, home.ddg1.c.1(2017)5906281, http://www.statewatch.org/news/2017/nov/eu-com-letter-to-ep-readmissions.pdf [Accessed 11 October 2018].

${ }^{19}$ Cassarino, "Informalizing the EU Readmission Policy" (2018), p.91.
} 
Notwithstanding the multiple references contained in the TEU, EU primary sources do not define the rule of law principle. Thus, and considering its capacity to encompass a whole subset of rules that describe a certain way of living together in modern societies, ${ }^{20}$ the rule of law concept demands some clarifications

In 2014, in the context of its proposed rule of law framework for the Union, ${ }^{21}$ the Commission attempted to identify the main components of the rule of law. Relying heavily on the earlier Venice Commission report on the topic, ${ }^{22}$ it defined the rule of law as an umbrella encompassing a series of justiciable principles, namely "legality [...]; legal certainty [...]; prohibition of arbitrariness of the executive powers $[\ldots]$; independent and effective judicial review, including respect for fundamental rights [...]; [and] equality before the law". ${ }^{23}$ This definition of the rule of law shows that the principle has at least three dimensions: an institutional dimension, related to the very distribution of public powers in a constitutional order; a procedural dimension, related to public participation in the 'making' of the law and individual rights in judicial proceedings; as well as a substantive dimension, that corresponds to the paramount obligation to respect fundamental rights in all instances. Part of the doctrine has dealt with the three-faceted nature of the principle, by affirming that the concepts of preeminence of the law, democracy, and fundamental rights protection are inextricably linked and that they intersect in the rule of law principle. ${ }^{24}$

\footnotetext{
${ }^{20}$ See L. Pech, "The Rule of Law as a Constitutional Principle of the European Union", Jean Monnet Working Paper 4/2009, p 49.

${ }^{21}$ The rule of law framework consists of a three-stage structured dialogue between the Commission and a member state, to prevent the emergence of a "systemic threat to the rule of law" that would need to be addressed under art. 7 TEU. See Commission, “A new EU Framework to strengthen the Rule of Law” COM(2014) 158 final.

${ }^{22}$ Report of the Venice Commission of 4 April 2011, Study No. 512/2009 (CDL-AD(2011)003rev).

${ }^{23}$ Annexes 1 to 2 to Commission, "A New Framework to Strengthen the Rule of Law" COM(2014) 158 final.

${ }^{24}$ L. Pech, "Rule of Law as a Guiding Principle of the European Union's External Action", CLEER Working Paper 3/2012.
} 
According to the Council of Europe, attempting to distinguish the rule of law from any of its three components would compromise its fundamental function, namely the reduction of arbitrariness in the exercise of public power. ${ }^{25}$ This essential function is aptly summarized by Konstantinides, when he defines the rule of law as a "constitutional controlling factor" ${ }^{26}$ The fundamental objective of limiting arbitrariness in the EU can only be reached if democracy, fundamental rights protection, and preeminence of the law are all coherently integrated within the rule of law umbrella.

Key to all three facets of the Union's rule of law value is the concept of accountability, both judicial ${ }^{27}$ and democratic. ${ }^{28}$ Judicial accountability entails the amenability of the acts of public powers to independent judicial scrutiny, while democratic accountability implies an obligation to respond to the representatives of the people and, ultimately, to voters themselves. The absence of judicial and democratic accountability renders scrutiny as to the pre-eminence of the law impossible and paves the way for undisturbed and unsanctioned fundamental rights violations.

For this reason, the present article relies on the concept of accountability, both judicial and democratic, to verify whether the process of informalisation of the Union's external relations in the field of return compromises their rule of law compliance.

${ }^{25}$ Council of Europe (Committee of Ministers), "The Council of Europe and the Rule of Law - An overview", CM(2008) 170, 21 November 2008, para.28.

${ }^{26}$ T. Konstantinides, The Rule of Law in the European Union: The Internal Dimension (Oxford: Hart Publishing, 2017), p.12.

${ }^{27}$ On the importance of judicial accountability in the EU concept of rule of law see Konstantinides, The Rule of Law in the European Union (2017).

${ }^{28}$ On the inextricability of democratic accountability and the rule of law see, for example, J. Raitio, "Does the Concept of Rule of Law Have Any Material Content? A Nordic Point of View" (2017) 24 Maastricht Journal of European and Comparative Law 774. 


\section{... as Translated in the Field of the EU External Relations}

The accountability dimension of the rule of law principle is translated, in the area of the EU external relations, into a series of procedural and substantive norms.

First, art. 296(2) TFEU provides that the Union always has to explicitly indicate the legal basis (treaty article or articles) on which an act having legal effects is adopted. ${ }^{29}$ This is true for internal acts, as well as for international agreements, as long as they have legal effects. The choice of the legal basis must rest on "objective factors amenable to judicial review". ${ }^{30}$ The obligation to indicate the legal basis of EU acts is a direct consequence of the principle of conferral, defined in art. 5(2) TEU as implying that "the Union shall act only within the limits of the competences conferred upon it by the Member States in the [TEU and TFEU, together the 'Treaties'] to attain the objectives set out therein". This principle also applies to the Union's external action, as confirmed by art. 216(1) TFEU ${ }^{31}$ that exhaustively lists the circumstances under which the Union can conclude international agreements in a specific field. The obligation to indicate the legal basis of the acts adopted forces the institutions to justify their actions with respect to the principle of conferral. Therefore, it serves the purpose of ensuring the judicial accountability of EU institutions, whenever they decide to adopt an act having legal effects.

\footnotetext{
${ }^{29}$ Article 296(2) TFEU reads: "Legal acts shall state the reasons on which they are based and shall refer to any proposals, initiatives, recommendations, requests or opinions required by the Treaties."

${ }^{30}$ Tomana and Others v Council and Commission (C-330/15 P) EU:C:2016:601; [2016] 4 W.L.R. 161, at [37]; Parliament v Council (C-130/10) EU:C:2012:472, at [42]; Parliament v Council (C-155/07) EU:C:2008:605; [2009] 1 C.M.L.R. 23, at [34]; Commission v Council (C-94/03) EU:C:2006:2, at [34].

${ }^{31}$ Article 216(1) TFEU reads: "The Union may conclude an agreement with one or more third countries or international organisations where the Treaties so provide or where the conclusion of an agreement is necessary in order to achieve, within the framework of the Union's policies, one of the objectives referred to in the Treaties, or is provided for in a legally binding Union act or is likely to affect common rules or alter their scope."
} 
Secondly, the Treaties insert an element of democratic accountability in the phase of negotiation of international agreements. According to art. 218(2) TFEU, the decision to open negotiations and nominate the negotiator is taken by the Council, upon a recommendation of the Commission ${ }^{32}$; however, in all the circumstances listed in art. 218(6)(a), no international agreement can be concluded without the consent of the European Parliament. The consent of the European Parliament is necessary, inter alia, to conclude any international agreement that "cover[s] fields to which either the ordinary legislative procedure applies; or the special legislative procedure where consent by the European Parliament is required". Considering that, under art. 79(2) TFEU, measures in the field of "illegal immigration and unauthorized residence, including removal and repatriation of persons residing without authorization" must be adopted "in accordance with the ordinary legislative procedure", the conclusion of formal international agreements in the field of return always requires the consent of the European Parliament. This ensures the democratic accountability of the Council and the Commission, providing for the necessary involvement of an institution elected by EU citizens in the decision making process leading to the conclusion of international agreements on return.

Thirdly, international agreements must be published in the Official Journal of the European Union, together with the Council decision on their conclusion. ${ }^{33}$ This results from art. 297 TFEU, that imposes upon all EU institutions an obligation to publish in the Official Journal both legislative acts and "non-legislative acts adopted in the forms of regulations, directives or decisions, when the latter do not specify to whom they are addressed". Publication in the official gazette of the Union ensures transparency and accountability, putting any interested party in the position to consult the content of the relevant international agreement and contest it in court. It also allows public debate on the document at stake, increasing democratic oversight on it.

\footnotetext{
${ }^{32}$ The recommendation comes from the High Representative of the Union for Foreign Affairs and Security Policy if "the agreement envisaged relates exclusively or principally to the common foreign and security policy", as specified by art. 218(3) TFEU.

${ }^{33}$ See, for example, 2014/252/EU: Council Decision of 14 April 2014 on the conclusion of the Agreement between the European Union and the Republic of Turkey on the readmission of persons residing without
} 
Fourthly, international agreements can be made subject to judicial scrutiny in the context of various types of proceedings. When negotiated and concluded by the Union in accordance with the Treaties, international agreements are "binding upon the institutions of the Union and on its Member States", as specified by art. 216(2) TFEU. ${ }^{34}$ They uncontestably have binding legal effects, therefore their legality can be reviewed by the Court of Justice of the European Union ('CJEU'), in the context of a direct action. Indeed, art. 263 TFEU attributes to the CJEU the power to review, upon a request from an institution or an interested individual, the legality of acts of EU institutions and agencies "intended to produce legal effects vis-à-vis third parties" ${ }^{35}$ Moreover, art. 218(11) attributes to the European Court of Justice ('ECJ') the power to review ex ante, upon the request of a Union's institution or a Member State, the compatibility of an envisaged international agreement with the Treaties. The negative opinion that may be rendered by the ECJ at the issue of such a procedure is binding, as it prevents the envisaged agreement from entering into force, unless the Treaties are amended, or the incompatibilities identified by the ECJ eliminated. ${ }^{36}$ Finally, international agreements concluded by authorization, [2014] OJ L134/1, published together with the Agreement between the European Union and the Republic of Turkey on the readmission of persons residing without authorization, [2014] OJ L 134/3.

${ }^{34}$ For the effects of international agreements on the EU legal order see K. Lenaerts, "Direct Effect and Direct Applicability of International Law in EU Legal Order", in I. Govaere, E. Lannon, P. Van Elsuwege, and S. Adam (eds), The European Union in the World: Essays in Honour of Marc Maresceau (Leiden:Martinus Nijhoff Publishers, 2014), p.45; C. Kaddous, "Effects of International Agreements in the EU Legal Order", in M. Cremona and B. de Witte (eds), EU Foreign Relations Law: Constitutional Fundamentals (Oxford: Hart Publishing, 2008), p.291; and Á. Mohay, “The Status of International Agreements Concluded by the European Union in the EU Legal Order" (2017) 33 Pravni Vjesnik 151.

${ }^{35}$ Inter alia, Comunidad Autónoma de Madrid and Mintra v Commission (T-148/05) EU:T:2006:234, at [37]; Ayuntamiento de Madrid and Madrid Calle 30 v Commission (C-448/07) EU:C:2008:358, at [45]; and Eurocoton and Others v Council (C-76/01 P) EU:C:2003:511, at [56].

${ }^{36}$ This is a logical consequence of the aim of art. 218(11), repeatedly described by the Court as that "of forestalling complications which would result from legal disputes concerning the compatibility with the Treaties of international agreements that are binding upon the European Union" (inter alia, EU-Canada Passenger Name Record Agreement, Re (Opinion 1/15), EU:C:2017:592 (ECJ); [2018] 1 C.M.L.R. 36, at [69]; Accession of 
the Union in accordance with the procedure established in the Treaties are undoubtedly attributable to the Union's institutions. As a consequence, they may form the object of preliminary ruling procedures as to their validity and interpretation, according to art. 267 TFEU. ${ }^{37}$ They could even lead to noncontractual liability of EU institutions, according to art. 268 TFEU, if the relevant conditions are met. $^{38}$

In conclusion, the rule of law principle is translated, in the area of the EU external relations, in a series of Treaty provisions. To comply with the rule of law principle, the EU return policy should be conducted in conformity with those Treaty provisions and their aim, namely ensuring the judicial and democratic accountability of the Union's external action. In the following sections, we will show that the systematic informalisation of the EU return policy entails a bypassing of these guarantees. Hence, it compromises the rule of law compliance of the Union's action in the field.

the European Union to the European Convention for the Protection of Human Rights and Fundamental Freedoms, Re (Opinion 2/13) EU:C:2014:2454 (ECJ); [2015] 2 C.M.L.R. 21, at [145]; and International Child Abduction Convention, Re (Opinion 1/13) EU:C:2014:2303 (ECJ); [2015] 1 C.M.L.R. 30, at [47].

${ }^{37}$ According to settled case law, international agreements concluded by the Union can be reviewed in the context of preliminary ruling proceedings (see R\&V Haegeman Sprl v Belgium (Case 181/73) EU:C:1974:41 (ECJ); [1975] 1 C.M.L.R. 515, at [1]-[6]). The ECJ has interpreted international agreements in several preliminary rulings, such as Firma Brita GmbH v Hauptzollamt Hamburg-Hafen (C-386/08) EU:C:2010:91; and Simutenkov v Ministerio de Educación Y Cultura, Real Federación Española de Futbol (C-265/03) EU:C:2005:213; [2005] 2 C.M.L.R. 11 .

${ }^{38}$ Those conditions, enshrined in art. 340(2) TFEU as interpreted by the CJEU, are (i) an actual damage; (ii) an illegal conduct on the part of a Union's institution; (iii) a causal link between the two. See, inter alia, FIAMM and Others v Council and Commission (Joined Cases C-120/06 P and C-121/06 P) EU:C:2008:476, at [106]; Sison v Concil (T-341/07) EU:T:2011:687, at [28]; Safa Nicu Sepahan v Council (T-384/11) EU:T:2014:986, at [47]; and Pappalardo and Others v Commission (T-316/13) EU:T:2016:247, at [16]. 


\section{The Evolution of the EU Return Policy: Seeking New Routes}

\section{New Trends}

The cooperation of third countries on return is sought and obtained through various tools, that can be broadly divided into two categories: formal international treaties, on the one hand, and informal deals, on the other.

If both formal and informal international agreements have always existed in the short history ${ }^{39}$ of the Union's external action on return, ${ }^{40}$ their relative weight has suffered a progressive shift, with the second category becoming the standard avenue of cooperation in the field of readmission and return for EU institutional actors and their counterparties.

When mapping the new tools of international cooperation in the field of migration concluded between the EU and third countries in recent years, two complementary trends can be identified: (i) the decline in the use of formal international treaties, and (ii) the rise in the use of other forms of cooperation.

\footnotetext{
${ }^{39}$ The Union acquired competence in the field of return and readmission only in 1999, as a result of the entry into force of the Treaty of Amsterdam amending the Treaty on European Union, the Treaties establishing the European Communities and certain related acts, [1997] OJ C 340/115. Following the Amsterdam revision, art. 63(3)(b) of the Treaty establishing the European Community, [1997] OJ C340/173, conferred upon the Union the competence to adopt measures in the field of "illegal immigration and illegal residence, including repatriation of illegal residents".

${ }^{40}$ L. Gabrielli, "Multilevel Inter-Regional Governance of Mobility between Africa and Europe", GRITIM-UPF Working Paper 30/2016.
} 


\section{The Decline in the Use of Formal International Treaties}

The difficulties encountered by the Union in negotiating ${ }^{41}$ and implementing ${ }^{42}$ formal international treaties to facilitate the return of irregular migrants, also known as readmission agreements, partially explain the decline in their use. At times, the political situation rendered the negotiation of a readmission agreement impossible, leading to the desertion of formal treaties in favour of informal cooperation tools. For instance, the governments of Bangladesh and Mali have long opposed the launch of formal readmission negotiations with the $\mathrm{EU},{ }^{43}$ but have concluded (for Bangladesh) or are in the process of discussing (for Mali) informal Standard Operating Procedures on Readmission. At other times, the impossibility to negotiate a deal at the EU level pushed individual Member States to take the lead in the informalisation of readmission cooperation with specific third countries. A relevant example is the Memorandum of Understanding ('MoU') concluded between Italy and Libya in 2016,4 backed by EU institutions in terms of both political support and funding. ${ }^{45}$

${ }^{41}$ Coleman, European Readmission Policy (2009), p.209.

${ }^{42}$ Carrera, Implementation of EU Readmission Agreements (2016).

43 See Commission and EEAS, "Joint non-paper on enhancing cooperation on migration, mobility and readmission with Mali”, Annex to Note 6473/16 MIGR 35 COAFR 47, http://www.statewatch.org/news/2016/dec/eu-com-eeas-readmission-mali-6473-16.pdf [Accessed 15 October 2018]; Commission, "Fifth Progress Report on the Partnership Framework with third countries under the European Agenda on Migration" COM(2017) 471 final; and S. Shahariar Zaman, "Bangladesh opposes readmission pact with European Union”, Dhaka Tribune 4 January 2016, https://www.dhakatribune.com/uncategorized/2016/01/04/bangladesh-opposes-readmission-pact-with-europeanunion [Accessed 15 October 2018].

${ }^{44}$ Memorandum d'intesa sulla cooperazione nel campo dello sviluppo, del contrasto all'immigrazione illegale, al traffico di esseri umani, al contrabbando e sul rafforzamento della sicurezza delle frontiere tra lo Stato della Libia e la Repubblica Italiana (Roma, 2.02.2017), http://www.governo.it/sites/governo.it/files/Libia.pdf [Accessed 11 October 2018] (unofficial English translation at http://eumigrationlawblog.eu/wpcontent/uploads/2017/10/MEMORANDUM_translation_finalversion.doc.pdf [Accessed 11 October 2018]). It should be noticed that the Preamble of this MoU explicitly links back to informal cooperation tools established between Italy and Libya before the fall of Gaddafi's government. Such former cooperation tools already allowed 
When the difficulties lied in the implementation of readmission agreements already concluded, rather than in their negotiation, informal and more flexible tools were put in place to scale up or modify the conditions of the cooperation, de facto becoming the main framework governing return of irregular migrants. For example, the EU-Turkey statement of March $2016^{46}$ modified the terms of the 2014 readmission agreement, ${ }^{47}$ especially by anticipating the entry into force of the obligation for Turkey to readmit third country nationals. ${ }^{48}$ The close monitoring of the statement's implementation

for informal return-and-readmission practices, as shown by the return operations conducted from the Italian island of Lampedusa towards Libya in the early 2000s (see S. Hamood, "Europe's Security Approach Failing to Halt Migration from Libya" (2008) 10 International Journal on Multicultural Societies 128, p.138).

${ }^{45}$ See Council, "Malta Declaration by the Members of the European Council on the External Aspects of Migration: Addressing the Central Mediterranean Route" (La Valletta, 3 February 2017); Council, "Decision (CFSP) 2016/993 of 20 June 2016 Amending Decision (CFSP) 2015/778 on a European Union Military Operation in the Southern Central Mediterranean (EUNAVFOR MED Operation SOPHIA)", [2016] OJ L 162/18; and Commission, "Decision on the Establishment of a European Union Emergency Trust Fund for Stability and Addressing Root Causes of Irregular Migration and Displaced Persons in Africa" C(2015) 7293 final.

${ }^{46}$ See EU-Turkey Statement of 18 March 2016, European Council and Council Press Release 144/16, available at http://www.consilium.europa.eu/en/press/press-releases/2016/03/18/eu-turkey-statement/, according to which "Turkey and the EU recognise that further, swift and determined efforts are needed".

${ }^{47}$ Agreement between the European Union and the Republic of Turkey on the readmission of persons residing without authorization, [2014] OJ L 134/3.

${ }^{48}$ In fact, under art. 24 of the agreement between the EU and Turkey on the readmission of persons residing without authorization, the obligation to readmit non-nationals would only have entered into force on 1 October 2017, three year after the entry into force of the other parts of the agreement and sever months after the signing of the EU-Turkey statement. It should be noticed that, even after 1 October 2017, the implementation by Turkey of the obligation to readmit non-national was not satisfactory, according to the EU party (see Commission, "Seventh Report on the Progress Made in the Implementation of the EU-Turkey Statement" $\operatorname{COM(2017)} 470$ final, p.10). 
by the Commission ${ }^{49}$ seems to indicate the preponderance of this informal deal with respect to its formal counterpart.

The complexities linked to the negotiation and implementation of readmission agreements rendered them even more unpopular after the outbreak of the migration crisis in 2015 , which corresponded to a growing demand for flexibility and speed of action. ${ }^{50}$ Before the end of 2014, the EU had concluded 17 readmission agreements ${ }^{51}$ and the Commission had received by the Council negotiating mandates for five more. ${ }^{52}$ However, no readmission agreements have been concluded since 2015. Admittedly, these type of agreements have not been abandoned as cooperation tools, as shown by the launch of negotiations for new formal readmission agreements with Nigeria and Jordan, based on new mandates issued by the Council, as well as with Tunisia based on an earlier mandate. ${ }^{53}$ Nonetheless, they have clearly ceased to be the default or even the preferred method of establishing cooperation with third countries in the field of return and readmission.

${ }^{49}$ Seven progress reports on the implementation of the statement were produced between April 2016 and September 2017.

${ }^{50}$ See L. den Hertog, "EU Budgetary Responses to the 'Refugee Crisis': Reconfiguring the Funding Landscape”, CEPS Paper in Liberty \& Security in Europe No. 93, 2016; and S. Carrera, S. Blockmans, D. Gros, and E. Guild, “The EU's Response to the Refugee Crisis: Taking Stock and Setting Policy Priorities", CEPS Essay No. 20/2015.

51 With Hong Kong, Macao, Sri Lanka, Albania, Russia, Ukraine, FYROM, Bosnia and Herzegovina, Montenegro, Serbia, Moldova, Pakistan, Georgia, Armenia, Azerbaijan, Turkey and Cape Verde. Date of conclusion and links to texts available at https://ec.europa.eu/home-affairs/what-we-do/policies/irregularmigration-return-policy/return-readmission_en [Accessed 12 October 2018].

${ }^{52}$ In particular, Morocco, Belarus, Algeria, Tunisia and China. See P. García Andrade and I. Martín. "EU Cooperation with Third Countries in the Field of Migration” European Parliament Study (2015), p.37.

${ }^{53}$ European Migration Network, “2016 Annual Report on Migration and Asylum” (2017), p.80. 


\section{The Rise in the Use of Informal Cooperation Tools}

Informal cooperation tools have been increasingly used by the EU in recent years, ${ }^{54}$ both in practice and in the intentions of the institutions in charge. Well before the development of an autonomous EU return policy, informal tools - be it diplomatic assurances or soft law instruments - were used by certain Member States to achieve return policy objectives. ${ }^{55}$ The Union soon emulated these practices, then went on to develop its own informalisation strategy, when the initial faith in the effectiveness of formal readmission agreements negotiated at EU level faded. Already in the early days of the EU return policy, Frontex was given the power to conclude working arrangements with third countries. ${ }^{56}$ Those arrangements were concluded by the agency and foreign administrative authorities and were defined as operational in nature. By the time the Global Agenda on Migration ${ }^{57}$ was rebranded as Global Agenda on Migration and Mobility (GAMM) in $2011,^{58}$ the possibility of establishing informal return-and-readmission systems with partner countries was on the table not only for agencies, but also for Union's institutions more broadly. The Mobility Partnerships, to be developed as the standard bilateral cooperation tools under the GAMM, were conceived as informal political declarations coming jointly from the EU and the partner country and concerning, inter alia, readmission cooperation..$^{59}$

\footnotetext{
54 The tendency has been noted by Carrera (Implementation of EU Readmission Agreements) and Cassarino ("Informalizing the EU Readmission Policy").

${ }^{55}$ L. Gabrielli, "La Externalización Europea Del Control Migratorio. ¿La Acción Española Como Modelo?" (2017) Anuario CIDOB de la Inmigración, 126-152, at 131-132; M. Giuffré, “An Appraisal of Diplomatic
} Assurances One Year after Othman (Abu Qatada) v United Kingdom (2012)" (2013) 2 International Human Rights Law Review 266; and B. K. Blitz, "Libyan Nationals in the United Kingdom: Geopolitical Considerations and Trends in Asylum and Return” (2008) 10 International Journal on Multicultural Societies 106, p.108.

${ }^{56}$ Article 14 of Council Regulation (EC) No 2007/2004 of 26 October 2004 Establishing a European Agency for the Management of Operational Cooperation at the External Borders of the Member States of the European Union [2004] OJ L 349/1 (no longer in force).

${ }^{57}$ Council, "Global approach to migration: Priority actions focusing on Africa and the Mediterranean", doc. 15744/05, ASIM 66 RELEX 761, 13 December 2005, 
Since 2015, the sense of urgency surrounding the migration crisis allowed the Union's institutions to be more straightforward about their informalisation strategy and to normalise the use of informal tools in this policy field. The 2015 Agenda on Migration and subsequent Commission documents ${ }^{60}$ express the intention to increase return rates and improve informal operational cooperation with third countries. The European Migration Network’s 2016 Annual Report on Migration and Asylum dwells upon the need for informal cooperation "to achieve fast and operational returns" 61 and lists the numerous initiatives taken for this purpose by the EU. Those include the infamous EU-Turkey statement; the Joint Way Forward on migration issues between Afghanistan and the $\mathrm{EU}^{62}$; the http://register.consilium.europa.eu/doc/srv?l=EN\&f=ST\%2015744\%202005\%20INIT [Accessed 12 October 2018].

${ }^{58}$ Commission, "The Global Approach to Migration and Mobility" COM(2011) 743 final.

59 J.-P. Cassarino, "A Reappraisal of the EU's Expanding Readmission System" (2014) 49 The International Spectator 130, p.138; and Brocza and Paulhart, "EU Mobility Partnerships" (2015).

${ }^{60}$ Commission, “A European Agenda on Migration”, $\operatorname{COM(2015)~} 240$ final, pp.9-10; Commission, "EU Action Plan on Return", $\operatorname{COM}(2015) 453$ final, p.10; and Commission, "On a More Effective Return Policy in the European Union - A Renewed Action Plan", COM(2017) 200 final, pp.12-13. See also Council Conclusions "On Enhancing Return and Readmission of Illegally Staying Third Country Nationals" (8 June 2017), doc. 10112/17, MIGR 98 VISA 222 COMIX 424, point 5, http://data.consilium.europa.eu/doc/document/ST-101122017-INIT/en/pdf [Accessed 12 October 2018]; Letter of the director general of DG HOME, "EU readmission developments - State of play October 2017", http://www.statewatch.org/news/2017/nov/eu-com-letter-to-epreadmissions.pdf [Accessed 12 October 2018]; and Commission "Towards a more efficient and credible EU return policy" https://ec.europa.eu/home-affairs/sites/homeaffairs/files/what-we-do/policies/european-agendamigration/20171114_factsheet_towards_an_efficient_and_credible_eu_return_policy_en.pdf $\quad$ A Accessed 12 October 2018].

${ }^{61}$ European Migration Network, "2016 Annual Report on Migration and Asylum”.

62 "Joint Way Forward on Migration Issues between Afghanistan and the EU", 4 October 2016, https://eeas.europa.eu/headquarters/headquarters-homepage/11107/joint-way-forward-on-migration-issues-

between-afghanistan-and-the-eu_en [Accessed 12 October 2018]. 
Standard Operating Procedures concluded with Bangladesh and discussed with Mali ${ }^{63}$; as well as, more broadly, the Partnership Framework approach proposed by the Commission in $2016 .{ }^{64}$ The latter is intended to become the standard negotiating format in the field of return and is, in many ways, the heir of the GAMM. ${ }^{65}$

63 "EU-Bangladesh Standard Operating Procedures for the Identification and Return of Persons without an Authorisation to Stay", text available as Annex 1 to Commission, "Decision on the signature of the EUBangladesh Standard Operating Procedures for the Identification and Return of Persons without an Authorisation to Stay" C(2017) 6137 final.

${ }^{64}$ Commission "Establishing a New Partnership Framework with Third Countries under the European Agenda on Migration", $\operatorname{COM}(2016) 385$ final.

${ }^{65}$ Commission "Establishing a New Partnership Framework with Third Countries under the European Agenda on Migration”, $\operatorname{COM(2016)~} 385$ final, p. 5. 
The Partnership Framework entails the negotiation of "migration compacts" with third countries. Even though the term "compact" generally refers to emergency tools, aimed at responding to temporary situations of crisis,${ }^{66}$ in the context of the Partnership Framework, compacts become the standard ways of obtaining third countries' cooperation on return. This is done through the linkage between migration and a whole set of unrelated policy areas, such as trade and development aid. ${ }^{67}$ The Commission's intention is to streamline the Partnership Framework approach in order to enforce more strictly than before what has been defined as "migration conditionality", ${ }^{68}$ namely the choice to render cooperation on migration a precondition for the good development of relations between Union and third countries in other fields. The Commission's declarations concerning the political nature of migration compacts confirm their objective of quickly achieving concrete results on migration cooperation, namely an increase in the number and speed of return operations. ${ }^{69} \mathrm{As}$ flexibility and speed are key objectives of migration compacts - especially since 2015, because of the political attention devoted to the migration crisis ${ }^{70}$ - informality and the bypassing of heavy procedures are of the essence. ${ }^{71}$

\footnotetext{
${ }^{66}$ Panizzon, "The Global Migration Compact" (2017), p.24.

${ }^{67}$ Commission "Establishing a New Partnership Framework with Third Countries under the European Agenda on Migration", $\operatorname{COM(2016)} 385$ final, p.8; and Panizzon, "The Global Migration Compact" (2017).

${ }^{68}$ N. Koenig, “The EU’s External Migration Policy: Towards Win-win-win Partnerships“"(2017) Jacques Delors Institut, $\quad$ Policy $\quad$ Paper $\quad$ no. $\quad 190, \quad$ http://www.delorsinstitut.de/2015/wp-
} content/uploads/2017/04/20170406_ExternalMigrationPolicy-NKoenig.pdf.

${ }^{69}$ Commission "Establishing a New Partnership Framework with Third Countries under the European Agenda on Migration", $\operatorname{COM}(2016)$ 385, p.7. See also European External Action Factsheet, "Migration Partnership Framework, a New Approach to Better Manage Migration" (7 June 2016) available at https://eeas.europa.eu/sites/eeas/files/factsheet_ec format_migration_partnership_framework_update_2.pdf

${ }^{70}$ Commission, "First Progress Report on the Partnership Framework with Third Countries under the European Agenda on Migration" COM(2016) 700 final, p.3.

${ }^{71}$ Cassarino, "Informalizing RU Readmission Policy” (2018), p.90. 
In conclusion, the EU return policy has been progressively informalised. The use of informal cooperation tools, first adopted at the level of certain Member States, was progressively normalised and streamlined also at EU level, especially in the favourable political climate that followed the outbreak of the migration crisis

In the next sections, we will see that the resulting informal deals raise problems of compatibility with the rule of law, as translated in the Treaties' provisions on the Union's external action. The problems relate, first and foremost, to the difficulty of establishing whether or not informal deals produce legal effects.

\section{The Legal Effects of Informal Agreements}

The applicability of most of the provisions of the Treaties that ensure the judicial and democratic accountability of the Union's external action depends on the effects of the deal at stake. Article 296(2) TFEU imposes upon the EU institutions the obligation to indicate the legal basis of their "legal acts", and art. 263 TFEU only allows for judicial scrutiny of acts "intended to produce legal effects vis-à-vis third parties". Moreover, according to art. 216(2) TFEU, international agreements governed by Title V TFEU are "binding upon the institutions of the Union and its Member States". This may be read - and is read by the EU institutions - as meaning that, if the Union intends to conclude a non-binding agreement, it is not restrained by the procedural guarantees enshrined in that Title. Such an interpretation writes off the need to obtain the consent of the European Parliament and eliminates the possibility of requesting ex ante judicial review of informal agreements. 
For the above reasons, the drafters of informal deals pay a particular attention to the language used, in order to present the content of the deals as non-binding and exclude the applicability of all the rule of law guarantees that a binding nature would entail. ${ }^{72}$ This tendency is well exemplified by three informal deals concluded in the aftermath of the migration crisis whose text is publicly available: the EU-Turkey statement, the Joint Way Forward on migration Issues between Afghanistan and the EU, and the EU-Bangladesh Standard Operating Procedures on return. Both the EU-Afghanistan Joint Way Forward and the EU-Bangladesh Standard Operating Procedures contain clauses explicitly stating that their respective instruments are "not intended to create rights and obligations under international law". The EU-Turkey statement, albeit less explicitly, demonstrates a similar disposition when listing "action points" rather than obligations or commitments.

Notwithstanding this, the question whether or not the three deals examined produce legal effects has no straightforward answer, because the capacity of an act to produce legal effects does not depend on the name given to it by its parties or on the form in which it is adopted, ${ }^{73}$ but must be inferred based on its substance. ${ }^{74}$ The factors taken into account to determine whether or not an act produces legal effects include its content and the circumstances surrounding its adoption ${ }^{75}$; the intention of the parties $^{76}$; and its wording. ${ }^{77}$ Indeed, it is at least arguable that the three deals be intended to produce legal effects. All three documents contain expressions modelled on the language of formal international agreements, with an insistent use of the modal "will", that generally accompanies the undertaking of obligations. ${ }^{78}$ They provide for joint working groups to monitor their respective implementation ${ }^{79}$ and list very detailed commitments on the issuance or acceptance of certain travel documents, ${ }^{80}$ as well as on the maximum number of return flights or returnees allowed within a certain time period. ${ }^{81}$ They even contain provisions related to the date of start of the cooperation, modification, renewal, and withdrawal within established time limits. ${ }^{82}$

\footnotetext{
${ }^{72}$ See, for example, the guidelines contained in the Commission "Vademecum on the EU external action" SEC(2011)881, http://ec.europa.eu/transparency/regdoc/rep/2/2011/EN/2-2011-881-EN-1-0.Pdf [Accessed 12 October 2018], pp.43-44.

${ }^{73}$ Commission v Council (C-425/13) EU:C:2015:483; [2016] 1 C.M.L.R. 11, at [26]; Commission v Council (C28/12) EU:C:2015:282; [2015] 3 W.L.R. 647, at [14]; Parliament v Council (Joined Cases C-181/91 and C-
} 
It must be added that the legal effects of a deal cannot be limited to the conferral of rights and the imposition of obligations upon its signatories, but must necessarily encompass its content, especially its consequences on the fundamental rights of third parties. As discussed above, respect for fundamental rights is one of the three facets of the rule of law in the EU, without which the latter is only an empty procedural vessel. Denying the necessity to hold institutions and Member States democratically and judicially accountable for actions that impact upon fundamental rights would

248/91) EU:C:1993:271, [1994] 3 C.M.L.R. 317, at [13]; and Commission v Council (ERTA) (Case 22/70) EU:C:1971:32 (ECJ), [1971] C.M.L.R. 335, at [42].

${ }^{74}$ Commission v Council (C-425/13) EU:C:2015:483; [2016] 1 C.M.L.R. 11, at [27]; Netherlands v Commission (C-147/96), EU:C:2000:335, at [27]; and IBM v Commission (Case 60/81) EU:C:1981:264 (ECJ); [1981] 3 C.M.L.R. 635, at [9].

${ }^{75}$ Parliament v Council (Joined Cases C-181/91 and C-248/91), EU:C:1993:271, [1994] 3 C.M.L.R. 317, at [4]; and Commission v Council (C-27/04) EU:C:2004:436, at [44]-[51].

${ }^{76}$ France v Commission (C-233/02) EU:C:2004:173, at [42]; and Athinaïki Techniki v Commission (C-521/06 P) EU:C:2008:422, [2008] 3 C.M.L.R. 34 , at [42]-[46].

77 France v Commission (Case C-327/91) EU:C:1994:305; [1994] 5 C.M.L.R. 517, at [15]; and France v Commission (C-233/02) EU:C:2004:173, at [43].

${ }^{78}$ As the Commission itself seems to recognize in its "Vademecum on the EU external action".

${ }^{79} \mathrm{Pt}$ IV of EU-Afghanistan Joint Way Forward on Migration Issues; point 6 of EU-Bangladesh Standard Operating Procedures on Return; and second to last paragraph of EU-Turkey statement.

${ }^{80} \mathrm{Pt}$ II of EU-Afghanistan Joint Way Forward on Migration Issues and points 1 to 4 of EU-Bangladesh Standard Operating Procedures on Return.

${ }^{81}$ Pt III of EU-Afghanistan Joint Way Forward on Migration Issues; point 6 of EU-Bangladesh Standard Operating Procedures on Return; and action point 2) of the EU-Turkey statement.

${ }^{82}$ Pts VI, VIII and IX of EU-Afghanistan Joint Way Forward on Migration Issues; point 6 of EU-Bangladesh Standard Operating Procedures on Return; and action points 1) and 6) EU-Turkey statement. Provisions of these kind are typical of those international agreements that are intended to provide legal effects. See, in this respect, Opinion of AG Sharpston of 26 November 2015 in Council v Commission (C-660/13) EU:C:2015:787, at [67]; and Commission "Vademecum on the EU external action". 
deprive the rule of law of its essential controlling function, and prevent any actual limitation of arbitrary decision making in the EU return policy field. Thus, the consequences of informal deals on migrants' fundamental rights must be taken into account when establishing whether or not they produce legal effects. As to the three deals examined in the present section, namely the EU-Turkey statement, the EU-Afghanistan Joint Way Forward, and the EU-Bangladesh Standard Operating Procedures, they have at least the potential to affect several fundamental rights of migrants, including their rights to non-refoulement, to effective judicial protection, and to request asylum. This capacity of informal, i.e. soft-law, deals to compromise fundamental rights protected by hard laws of constitutional relevance, such as the EU Charter of Fundamental Rights and the European Convention of Human Rights, has attracted the attention of many commentators. ${ }^{83}$

The above observations show that strong arguments can be brought forward in favour of the conclusion that the three deals examined produce legal effects, both on their signatories and on third parties. Nonetheless, the institutions' intention to present these deals as non-binding is enough to generate uncertainty on their legal effects. This uncertainty, in its turn, is sufficient to substantially diminish the democratic and judicial accountability of the EU return policy.

\footnotetext{
${ }^{83}$ V. Moreno-Lax, "The Migration Partnership Framework and the EU-Turkey Deal: Lessons for the Global Compact on Migration Process?", in in T. Gammeltoft-Hansen, E. Guild et al. "What Is a Compact? Migrants' Rights and State Responsibilities Regarding the Design of the UN Global Compact for Safe, Orderly and Regular Migration" RWI Working Paper 1/2017, p.29; M. J. Alpes, S. Tunaboylu, and I. van Liempt, "Human Rights Violations by Design: EU-Turkey Statement Prioritises Returns from Greece Over Access to Asylum”, EUI Policy Brief 2017/29; Panizzon, “The Global Migration Compact and the Limits of 'Package Deals' for Migration Law and Policy”(2017), p.21; and Cassarino, “Informalizing RU Readmission Policy” (2018), p.94.
} 
Informal Agreements and the Rule of Law: Remaining under the Radars

To understand why the simple uncertainty on the nature of the effects of informal deals is sufficient to reduce the accountability of the Union's return policy, we need to examine the scope of application of the Treaty provisions described above. As mentioned, these provisions ensure respect for the rule of law principle in the area of the EU external relations. 
First, we have seen that art. 296(2) TFEU imposes upon EU institutions the obligation to specify the legal basis on which they adopt "legal acts". EU institutions' decisions to conclude formal international agreements certainly fall within the definition of "legal acts" under art. 296(2) TFEU, ${ }^{84}$ but the situation is less straightforward for informal deals. In practice, the institutions consider art. 296(2) inapplicable to informal deals, as shown by the circumstance that the three deals examined above do not specify the legal basis upon which they are adopted ${ }^{85}$ The EU-Turkey statement simply specifies that "the EU and Turkey today decided to end the irregular migration from Turkey to the EU"86; the EU-Afghanistan Joint Way Forward only refers to the "unprecedented refugees and migration challenges" faced by the two parties ${ }^{87}$; and the EU-Bangladesh Standard Operating Procedures merely indicate their aim, namely that of "establishing effective and transparent procedures for the identification and safe and orderly return of persons who have no legal basis to stay in the territory of the requesting country" ${ }^{88}$ The lack of an explicit legal basis has a negative impact on both the judicial and the democratic accountability of informal deals.

Secondly, formal readmission agreements are negotiated following the procedure established by art. 218 TFEU and they cannot be concluded without the consent of the European Parliament.

\footnotetext{
${ }^{84}$ See, inter alia, Commission v Council (C-94/03) EU:C:2006:2, at [34]; and Cartagena Protocol on Biosafety, $\operatorname{Re}($ Opinion 2/00) EU:C:2001:664 (ECJ); [2002] 1 C.M.L.R. 28, at [22].

85 This corresponds to the view expressed by the Commission in its "Vademecum on the EU external action", p.13. See also, with respect to the lack of necessity to specify -and therefore disclose - the legal basis of the EU-Turkey statement, Access Info Europe v Commission (T-851/16) EU:T:2018:69; Access Info Europe v Commission (T-852/16) EU:T:2018:71; and C. Molinari, “The General Court's Judgments in the Cases Access Info Europe v. Commission (T-851/16 and T-852/16): A Transparency Paradox?”, European Papers European Forum, Insight of 2 October 2018, http://www.europeanpapers.eu/en/europeanforum/general-courtsjudgments-cases-access-info-europe-v-commission [Accessed 15 October 2018].

${ }^{86}$ EU-Turkey statement, para.4.

${ }^{87}$ EU-Afghanistan Joint Way Forward, Introduction, para.1.

${ }^{88}$ EU-Bangladesh Standard Operating Procedures, para.1.
} 
EU institutions clearly consider art. 218 TFEU inapplicable to informal deals. The EU-Tukey statement was negotiated in the context of an EU-Turkey Joint Action plan on migration, and activated and enforced through meetings between "Members of the Council" and "their Turkish counterpart" ${ }^{89}$ with the support of the Commission ${ }^{90}$; the EU-Afghanistan Joint Way Forward was negotiated by the European External Action Service in the context of the relevant Partnership Framework ${ }^{91}$; and the EUBangladesh Standard Operating Procedures were negotiated and signed by the Commission, with the endorsement of the Council. ${ }^{92}$ The European Parliament was not involved in the negotiation phase, nor requested to give its consent to the conclusion of such informal deals. The fluid and unregulated nature of the negotiation of informal deals and the lack of involvement of the European Parliament have a negative impact on their democratic accountability.

\footnotetext{
${ }^{89}$ EU-Turkey statement, para.1. See reconstruction of the negotiating iter contained in NFv Council (T-192/16) EU:T:2017:128, at [1]-[9].

${ }^{90}$ Commission, "Next Operational Steps in EU-Turkey Cooperation in the Field of Migration", $\operatorname{COM}(2016) 166$ final.

${ }^{91}$ See Remarks by Commissioner Avramopoulos at the European Parliament Plenary Debate: Afghanistan Joint way forward on migration issues, 26 October 2016, https://ec.europa.eu/commission/commissioners/20142019/avramopoulos/announcements/remarks-commissioner-avramopoulos-european-parliament-plenary-debate-
} afghanistan-joint-way-forward_en [Accessed 12 October 2018].

${ }^{92}$ See General Affairs Council, Outcome of $3560^{\text {th }}$ meeting of 25 September 2017, doc.. 12484/17, PRESSE 46 PR CO 46, p.10. 
Thirdly, pursuant to art. 297 TFEU, formal readmission agreements must be published on the Official Journal of the European Union. EU institutions clearly consider informal deals to fall outside the scope of application of this provision. Admittedly, the content of the EU-Turkey satement and of the EU-Afghanistan Joint Way Forward is available in the form of press releases, respectively on the webpages of the Council and of the European External Action Service, while the text of the EUBangladesh Standard Operating Procedures on Return is published on the Council's website in annex to the Commission decision to sign them. However, these different forms of publication do not respond to a publishing obligation, comparable to the one enshrined in art. 297 TFEU and applicable to formal international agreements. For this reason, the content of informal deals may or may not be made public, and this makes it more difficult - or even impossible, in case of a lack of publication - to challenge them in court and publicly debate their content. 
Fourthly, the legality of formal readmission agreements can be reviewed in the context of a direct action under art. 263 TFEU. The uncertainty upon the nature of the effects of informal deals renders the viability of a direct action problematic and, in any event, aggravates the position of potential applicants, that will have to prove that the deal at stake is "intended to produce legal effects vis-à-vis third parties". Equally subject to the condition that the deal produces binding legal effects is the possibility of ex ante judicial review under art. 218(11) TFEU, as confirmed by the Court in various instances. ${ }^{93}$ This preventive form of jurisdiction is further hindered by the lack of parliamentary involvement in the negotiating procedure, that reduces the likelihood of a challenge to the envisaged deal. In addition, uncertainties concerning the binding nature of a certain deal render proof of the existence of a direct causal $\operatorname{link}^{94}$ in a compensation claim more burdensome. Indeed, it seems, difficult to prove that a non-binding commitment be the direct and immediate cause of a specific damage..$^{95}$

${ }^{93}$ The OECD Understanding on a Local Cost Standard, Re (Opinion 1/75) EU:C:1975:145 (ECJ); [1976] 1 C.M.L.R. 85, p.1360; GATS Agreements, Re (Opinion 1/08) EU:C:2009:739 (ECJ); [2010] 2 C.M.L.R. 13, at [107]; and EU-Canada Passenger Name Record Agreement, Re (Opinion 1/15), EU:C:2017:592 (ECJ); [2018] 1 C.M.L.R. 36, at [69].

${ }^{94}$ The existence of a direct causal link between an illegal act of a Union institution and the damage suffered by the applicant is one of the conditions to establish the Union's liability in compensation claims brought under art. 268 TFEU. See, for example, Nikolaou v Cour des Comptes (C-220/13 P) EU:C:2014:2057, at [52]; and Commission v Systran and Systran Luxembourg (C-103/11 P) EU:C:2013:245; [2013] 3 C.M.L.R. 25, at [60].

${ }^{95}$ See Ledra Advertising v Commission and ECB (Joined Cases C-8/15 P to C-10/15 P) EU:C:2016:701; [2017] 1 C.M.L.R. 35. 
Finally, if published in the form of press releases, informal deals generally do not bear signatures, so that it might be difficult to establish whether the entity undertaking the relevant obligations is the EU, or rather its Member States. This is an obstacle to any judicial challenge of such deals, as shown by the outcome of the only case concerning the EU-Turkey statement brought, so far, before the General Court. ${ }^{96}$ The applicant in this case had brought an action for annulment of the EU-Turkey statement, qualifying it as an international agreement between the Council and Turkey. The reasons for such qualification were far from weak, as the deal repeatedly refers to the European Union, rather than its Member States, when explaining that "Turkey and the European Union reconfirmed their commitment to the implementation of their joint action plan ... Turkey and the $E U$ also agreed to continue stepping up measures against migrant smugglers" (emphasis added) and, even more indicatively, that "the $E U$ and Turkey today decided to end the irregular migration from Turkey to the $E U$. In order to achieve this goal, they agreed on the following additional action points" (emphasis added). Notwithstanding this language, the General Court decided to deny its jurisdiction on the matter, following the Council's contention that "the expression Members of the European Council contained in the EU-Turkey statement must be understood as a reference to the Heads of State and Government of the Member States of the European Union". ${ }^{97}$ The example of this General Court judgment, currently under appeal,,$^{98}$ shows how the lack of clarity concerning the paternity of a deal can substantively reduce judicial accountability. The lack of precision as to the paternity of informal deals offers the judge a tempting technical escape route from politically sensitive cases. If coupled with the judge's unwillingness to stand up for the rule of law in delicate areas, such as that of migration, ${ }^{99}$ the difficulties in establishing whether a deal is attributable to the EU constitute obstacles

\footnotetext{
${ }^{96}$ NF v Council (T-192/16) EU:T:2017:128.

${ }^{97}$ NF v Council (T-192/16) EU:T:2017:128, at [57].

${ }^{98}$ NF v Council (C-208/17 P), in progress.

${ }^{99}$ See I. Goldner Lang, “Towards 'Judicial Passivism' in EU Migration and Asylum Law? Preliminary Thoughts for the Final Plenary Session of the 2018 Odysseus Conference” (24 January 2018) EU Immigration Law and Policy Blog, http://eumigrationlawblog.eu/towards-judicial-passivism-in-eu-migration-and-asylum-law-
} 
not only to direct actions under art. 263 TFEU, but also to preliminary rulings under art. 267 TFEU and actions for damages under art. 268 TFEU. In fact, all these judicial remedies are available only when the contested act is attributable to the Union. ${ }^{100}$

In conclusion, the institutions' intention to present informal deals as non-binding, be it well founded or not, renders the applicability of all the Treaty provisions examined above at least doubtful. The situation would be aggravated if future judgments were to confirm the General Court's formalistic approach $^{101}$ to informal deals. The deferential stance adopted by the General Court in the mentioned case prevents the judges from performing their constitutional role, namely guaranteeing (i) accountability of the Union's action, (ii) fundamental rights compliance, and (iii) pre-eminence of the law, including the EU law principles of sincere cooperation and preemption in areas of shared competences. ${ }^{102}$

\section{Conclusion: The Rule of Law at Sea}

preliminary-thoughts-for-the-final-plenary-session-of-the-2018-odysseus-conference/ $\quad$ Accessed 15 October 2018].

${ }^{100}$ Arts 267(1)(b) and 340(2) TFEU.

${ }^{101}$ V. Moreno-Lax, “The Migration Partnership Framework and the EU-Turkey Deal: Lessons for the Global Compact on Migration Process?" (2017), p.31; and E. Cannizzaro, "Denialism as the Supreme Expression of Realism - A Quick Comment on NF v. European Council” (2017) 2 European Papers 251.

${ }^{102}$ On the essential function of the EU adjudicator in for the Union's notion of rule of law see Konstantinides, The Rule of Law in the European Union (2017), pp.111-124. 
The analysis developed in this article has been guided by the following question: does the systematisation in the use of informal tools affect the rule of law compliance of the Union's return policy? To answer this question, we started by setting out the relevant conceptual framework. We provided a definition of the term informalisation, as used in the context of EU migration law, and of the rule of law principle. We identified judicial and democratic accountability as core elements of the Union's conception of the rule of law, that encompasses pre-eminence of the law, democracy, and fundamental rights protection. Then, we examined the Treaty articles that ensure the accountability of the Union's external relations. These articles are those that provide for judicial remedies and impose upon the Union's institutions the obligations to indicate the legal basis of their action, to obtain the consent of the European Parliament when concluding formal agreements, and to publish them in the Official Journal.

After having set out the conceptual premises of the article, we answered the research question through an analysis of the most recent developments in the area of the EU return policy. We showed that two parallel and complementary trends have characterised the evolution of the EU external relations on return: a decrease in the use of formal international treaties, and an increase in the use of informal cooperation tools. We observed that the nature of the legal effects of informal cooperation tools is debatable, taking as an example three informal deals concluded after 2015: the EU-Turkey statement; the EU-Afghanistan Joint Way Forward; and the EU-Bangladesh Standard Operating Procedures. Finally, we proved that the uncertainty concerning the legal effects of informal deals substantially undermines the applicability to such deals of a series of Treaty norms that guarantee judicial and democratic accountability of the Union's external action. Such norms provide for judicial remedies and impose upon the Union's institutions the obligations to indicate the legal basis of their action, to obtain the consent of the European Parliament when concluding formal agreements, and to publish them in the Official Journal.

Based on the above analysis, we can make the following observations. 
The EU return policy has been progressively informalised. The process of informalisation has become more and more systematic, with informal agreements growing into the new standard way of conducting return and readmission cooperation. The EU institutions act on the premises that informal deals are not binding and lack legal effects. However, this position is disputable, at least with respect to the three deals examined as a case-study. In fact, these informal cooperation tools present several elements that might lead to the conclusion that they are intended to bind their signatories. More fundamentally, their content has the potential to affect the legal situation of migrants, especially their fundamental rights to non-refoulement, asylum and effective judicial protection.

The institutions' claim that informal deals lack legal effects entails the de facto inapplicability of a series of Treaty articles detailing decision-making procedures and providing for judicial remedies. These Treaty articles are expressions of the rule of law principle, in that they ensure the democratic and judicial accountability of the Union's institutions in the field of EU external relations.

Systematising the use of informal deals - while alleging the non-applicability to the latter of judicial and democratic accountability mechanisms - means subtracting an expanding portion of the EU return policy from rule of law constraints. The consequences of the normalisation of informal policy-making in this field are amplified if the judiciary adopts a formalistic approach when assessing the effects of cooperation tools, to avoid robust rule of law scrutiny of politically sensitive policy areas.

This avoidance of accountability is especially troubling if we consider that informal deals in the field of return affect fundamental rights, which constitute one of the three essential facets of the rule of law conceptions prevailing in the EU. Freeing areas of governance with clear fundamental rights implications from judicial and democratic guarantees sets a dangerous premise, in that it reduces the rule of law to an empty promise, incapable of performing its controlling function when it would be needed the most. 